\title{
EFFECT OF HUMAN ACTIVITIES AND OIL POLLUTION ON THE MICROBIOLOGICAL AND PHYSICOCHEMICAL QUALITY OF UDU RIVER, WARRI, NIGERIA.
}

\author{
Efeitos da atividade humana e da contaminação por óleo \\ sobre a qualidade físico-química e microbiológica no \\ Rio Udu, Warri, Nigéria.
}

Aluyi, H. S. A, Ekhaise, F. O. Adelusi, D. M. Oviasogie, F. E.

\begin{abstract}
The effect of human activities and oil pollution on the microbiological quality of Udu River was investigated from September 2002 to January 2003. The microbiological parameters were carried out using the standard microbiological techniques. The bacterial and fungal loads were shown to be highest in the inhabited stations (2 and 3) with downstream (station 4) suffering from dilution effects of human activities and upstream (station 1) showing lower counts. Stations 2 and 3 were shown to record the highest heterotrophic microbial load $10.7 \times 10^{8} \mathrm{cfuml}^{-1}$ and $10.4 \times 10^{8} \mathrm{cfuml}^{-1}$ and $8.0 \times 10^{8} \mathrm{cfuml}^{-1}$ and $9.0 \times 10^{8} \mathrm{cfuml}^{-1}$ for bacterial and fungal isolates respectively. Total coliform counts ranges from $1.5-4.3 \times 10^{6}$ and $1.4-2.8 \times 10^{6}$ MPN100 $\mathrm{ml}^{-1}$ for stations 2 and 3. Microorganism isolated and characterized includes nine bacterial and four fungal genera. The bacterial isolates were Staphylococcus, Streptococcus, Proteus, Escherichia, Clostridium, Acetobacter, Salmonella, Pseudomonas, Micrococcus, and the predominant fungal isolates includes, Aspergillus, Penicillium, Geotrichum and Helminthosporium. The concentrations of total suspended solids, biochemical oxygen demand $\left(\mathrm{BOD}_{5}\right)$, conductivity, total iron, total solids, total copper and total dissolved solids were shown to be higher in stations 2 and 3 than station 1 which have no direct human activities. Similarly, the values obtained for salinity, total hardness and dissolved oxygen (DO) of the inhabited stations were shown to be lower than station 1. Correlation coefficient shows positive relationship between the different microbial populations and some physiochemical parameters studied.
\end{abstract}

Keywords: Human activities; Oil pollution; Heavy metals.

Researchers of Department of Microbiology, Faculty of Science, University of Benin, Benin City, Nigeria.

Author to correspondence: fredfldyn@yahoo.com 


\section{Resumo}

Os efeitos da atividade humana e da poluição por óleo sobre a qualidade microbiológica do Rio Udu foram avaliados de setembro de 2002 a janeiro de 2003. Os parâmetros microbiológicos foram estudados seguindo-se técnicas microbiológicas-padrão. As concentrações de bactérias e fungos mostraram-se máximas em áreas habitadas (2 e 3), e rio abaixo (estação 4), onde ele acaba sofrendo os efeitos da diluição da atividade humana. Rio acima (estação 1) detectou-se contagens mais baixas. Nas estações 2 e 3 observaram-se elevados níveis de micróbios heterotróficos $10,7 \times 10^{8} \mathrm{cfuml}^{-1}$ e $10,4 \times 10^{8} \mathrm{cfuml}^{-1}$; e 8,0 x $10^{8} \mathrm{cfuml}^{-1}$ e 9,0 x $10^{8} \mathrm{cfuml}^{-1}$ para bactérias e fungos isolados respectivamente. Também nas estações 2 e 3 a contagem de coliformes totais variou de 1,5-4,3 × $10^{6} \mathrm{e} \quad 1,4-2,8 \times 10^{6} \mathrm{MPN}^{2} 100 \mathrm{ml}^{-1}$, respectivamente. Os microrganismos isolados e caracterizados incluem nove tipos de bactérias e quatro de fungos. As bactérias isoladas foram Staphylococcus, Streptococcus, Proteus, Escherichia, Clostridium, Acetobacter, Salmonella, Pseudomonas, Micrococcu; , e os fungos foram predominantemente Aspergillus, Penicillium, Geotrichum e Helminthosporium. A concentração total de sólidos suspensos, a demanda bioquímica de oxigênio (DBO), a condutividade, o ferro total, os sólidos totais, o cobre total, e os sólidos dissolvidos totais mostraram-se maiores nas estações 2 e 3 do que na estação 1, a qual não sofre com as atividades humanas diretas. Da mesma maneira, os valores obtidos para salinidade, dureza total da água e oxigênio dissolvido (OD) dos locais habitados mostraram-se mais baixos que na estação 1. Os coeficientes de correlação mostraram uma relação positiva entre as diferentes populações de microrganismos e alguns parâmetros físico-químicos estudados.

Palavras-chave: Atividades humanas; Poluição por óleo; Metais pesados.

\section{Introduction}

Water constitutes an integral part of man's life as well as the earth's surface, hence the need for continuous research about impact on its quality due to one form of human activity or the other. Of all the water found on earth, marine constitutes the largest with about $97 \%$. Fresh waters, although a small part of the waters on earth, are extremely important as source of drinking water. In many locations the contamination of surface and subsurface waters by domestic and industrial wastes causes environmental problems (1).

The Udu River which is a tributary of the Warri River is located in Warri South Local Government Area of Delta State and spans over 48 $\mathrm{km} 2$. The river has its source from Aboh in Delta north, lying between longitude $6.20^{\circ} \mathrm{N}$ and latitude $5.45^{\circ} \mathrm{E}$. The river flows southwest to Warri where it is joined by a large number of creeks from where it empties into the very brackish Forcados river and finally into the Atlantic Ocean (2).

The river flows across a large uninhabited stretch of land. Companies involved in one form of marine activity or the other basically occupy the inhabited expanse of land. This rapid industrialization has led to alterations in the water quality of the river thus causing great concern for the immediate users of the river water and the larger society. The location of a jetty where people take boat straight from Ovwina to Igbudu (a central position of Warri main town) thereby avoiding the numerous traffic in the town has resulted in increased human activities along the course of the river. This is evident in higher faecal contamination of the river, urban run offs, abattoir effluent discharges, and organic and inorganic dumps around or directly into the river. The dumping of chemicals by companies like Nissco and Globester involved in the fabrication of oilrig platforms, has further led to great alterations of the bacteriological and physicochemical quality of the river.

The importance of water to humans has resulted in the sitting of most rural communities and industries as well as individual homes along the river course (3). Large amounts of water consumed by humans are form surface water, which includes rivers, streams, lakes, wetlands, groundwater (4). Water pollution is basically rendering the water the water unfit for human consumption and recreational purpose. The Udu River serves communities like Ujevwu, Egini, Aladja, and Ovwian where fishing serves as a major source of occupation for most inhabitants of theses communities. Other activities like swimming, bathing, dumping of sawdust and washing of clothes by the river are also a common feature of water pollution observed here. Thurman et al. (4) reported similar results where inhabitants in the rural communities rely on untreated natural water 
for use, especially in the developing countries of the world.

Increased human activities, the accidental and intentional dumping of pollutants, effluent discharges into this river has created growing environmental concerns, especially loss of commercial fisheries, contaminated seafood and species extinctions. This alteration in the water quality has increased the anxiety of the rural inhabitants, who have to travel great distance to other creeks to fish as well as shortage of good quality drinking water. Types and concentrations of contaminants in drinking water differ with location. In surface water the difference can also be attributed to nature of contaminants around the water body (5). Toxic chemicals and microbial pollutants are widespread. Lead, commonly used in plumbing conduit and fixtures until recently, was a serious contaminant especially to foetus and children. Anson and Ware (6) stated that the bacterial population in water is greatly influenced by oxygen, $\mathrm{pH}$, and temperature of a water body being one of the most important characteristics which determines to a considerable extent, the trends and tendencies of changes in its quality (7). This paper reports the effect of human activities and oil pollution on the microbiological and physicochemical qualities of Udu River, Warri, Nigeria.

\section{Materials and Methods}

\section{Source of samples}

Water samples were collected between September, 2002 and January, 2003 from four sampling stations designated 1 to 4 along the course of the river. Station 1 is an upstream and uninhabited with less human activities. The vegetation around this station is composed mainly of trees with branches extending and creating shade around the immediate bank of the river. Station 2 is $1 \mathrm{~km}$ downstream of station 1 and is located just by the Udu Bridge, the water here is polluted with high human activities like swimming, washing of clothes and logs, as well as discharge from boats buildings. Station 3 is about $1.2 \mathrm{~km}$ downstream of

Station 2, with a moderate flow rate and less human activities. The vegetation around this station is composed mainly of thick grasses, trees and others. The water is turbid, probably due to the effect of human activities such as disposal of sawdust from upstream. Station 4 is about $500 \mathrm{~m}$ downstream of station 3. It has a consistent flow rate with no direct human activity. The water is less turbid, clearer than upstream. The vegetation is composed mainly of thick palm trees and grasses.

\section{Sa mple collection}

Samples for bacteriological analysis were collected directly from the river in sterilized plastic containers. The cover of the bottle was removed and held in one hand while the bottle was held at the base with the other hand. It was the then plunged neck downwards below the surface of the water. It was titled until the neck pointed slightly upwards, with the mouth being directed towards the current. Samples for dissolved oxygen (DO) and biochemical oxygen demand (BOD) were collected in $250 \mathrm{ml}$ bottles with stoppers, one millimeter each of Winkler's solutions A and B were added to samples on site to fix the oxygen (8). The samples were collected between 7.00am and $9.00 \mathrm{am}$ and were transported to the laboratory for both bacteriological and physicochemical analyses and were analyzed with $6 \mathrm{~h}$ of collection.

The bacteriological parameters monitored include total viable aerobic count to isolate heterotrophic bacterial and fungal, total coliform counts, Escherichia coli counts, faecal Streptococci counts and Clostridium perfringens counts according to the methods of Gerhardt et al., (9). The isolation and identification of bacterial and fungal isolates were carried out in accordance with Bergey's Manual of Determinative Bacteriology $(9,10,11)$. The physicochemical parameters were studied in accordance with the standard methods of APHA (8).

\section{Results}

The highest total heterotrophic bacteria population of $10.7 \times 10^{8} \mathrm{cfuml}^{-1}$ was recorded in late January at downstream station 2 and the lowest count of $5.3 \times 10^{8} \mathrm{cfuml}^{-1}$ was recorded in the upstream station 1 in mid September. The highest aerobic pathogenic bacterial densities $9.110^{\circ} \mathrm{cfuml}$ 
${ }^{1}$ was recorded in January at downstream station 2 and the lowest $3.2 \times 10^{8} \mathrm{Cfuml}^{-1}$ in September in station 1. It was observed that both total heterotrophic and aerobic pathogenic bacterial population increased along the stations, from station 1 to station 3 with a short drop in station 4 (Table. $1)$.

The total hydrocarbon degrading microbial isolates showed a similar pattern as total heterotrophic and aerobic pathogenic bacteria, the microbial counts ranges from $3.1 \times 10^{8}$ cfuml $^{-1-1}$ - $5.4 \times 10^{8} \mathrm{cfuml}^{-1}$. The highest count $5.4 \times 10^{8} \mathrm{cfuml}^{-1}$ was recorded in downstream station 2 in late January and the lowest value was recorded in early September at station 4.

The total coliform counts were observed to fluctuate throughout the sampling period. The results showed that the total coliform population was lowest $\left(0.7 \times 110^{6} \mathrm{MPN} 100 \mathrm{ml}^{-1}\right)$ in mid September at station 4 while the highest density $\left(4.3 \times 10^{6} \mathrm{MPN}^{2} 100 \mathrm{ml}^{-1}\right)$ was recorded in January at station 2. Similar trend was observed in the population densities of faecal streptococci Clostridium perfringens in all the water-sampling stations. The population of E. coli in all the water sampling stations was moderate but significantly lower than that of coliforms. There was variation in the fungal population, which ranges from species to species, as some species of fungi were found more in uninhabited station than inhabited stations. Aspergillus niger and Geotrichum candidum were seen as the most predominant fungal species. Eleven microbial isolates were identified and characterized and these include nine bacterial and four fungal genera, Staphylococcus, Streptococcus, Proteus, Escherichia, Clostridium, Acetobacter, Salmonella, Pseudomonas, Micrococcus,
Aspergillus, Penicillium, Geotrichum and Helminthosporium.The eleven microbial isolates were frequently isolated from the upstream downstream station. The results of the occurrence and distribution of the microbial isolates is showed in Table 2. Station 1 showed a scanty distribution of the bacterial isolates, with the exception of $\mathrm{C}$. perfringens. Stations 2 and 3 were seen to be heavily loaded with the bacterial isolates, which is an evidence of the high human activities and the oil pollution effects of the different oil companies operating in the area. Among the fungal isolates, Aspergillus niger, A. flavus and Penicillum sp. were predominantly present in the first three stations. The physicochemical qualities of Udu River studied are showed in Table 3. During the periods of sampling, the flow rate ranged from 0.498 to $0.721 \mathrm{~ms}^{-1}$. The flow rate was highest at station 1 $\left(0.721 \mathrm{~ms}^{-1}\right)$ and lowest at station $4\left(0.498 \mathrm{~ms}^{-1}\right)$. Air and water temperature varied from $27.7-28.5^{\circ} \mathrm{C}$ and from 26.45 to $27.0^{\circ} \mathrm{C}$. The $\mathrm{pH}$ value of water varied from 6.14 to 6.73 . The total dissolved solids (TDS), total suspended solids (TSS) and total solids (TS) values varied from 24.03 to 67.35 ; from 42.98 to 105.06 and from 67.01 to 172.35 respectively; with stations 2 and 3 recording the highest values (Table.3). In contrast, conductivity, hardness, dissolved oxygen (DO), nitrate, sulphate, lead, chromium, cadmium decreased from September to January along the sampling stations. The BOD values of the water samples varied from 5.07 to 6.83 , the highest value was recorded in station 2. The correlation coefficient tests conducted for all the sampled stations between the microbiological and physicochemical parameters at $95 \%$ probability level showed mostly relationships in all the parameters. 


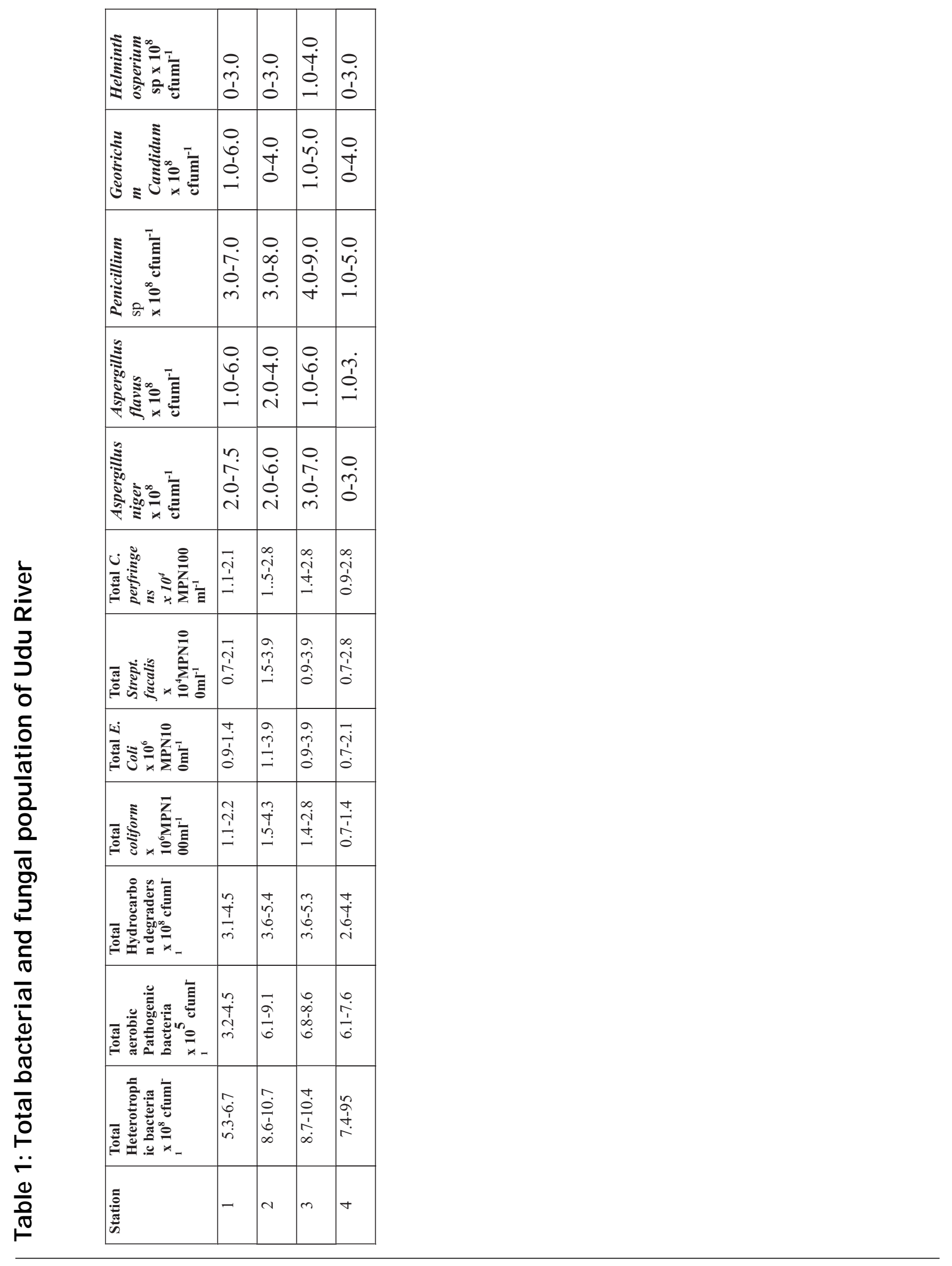

Estud. Biol., v. 28, n.62, p. 35-43, jan./mar. 2006 


\section{Table 2: Occurrence and spatial distribution of microbial isolates in Udu River}

\begin{tabular}{|c|c|c|c|c|c|c|c|c|c|c|c|}
\hline Isolate & Stati on & Sept. & Sept & Oct. & Oct. & Nov. & Nov. & Dec. & Dec. & Jan. & Jan. \\
\hline Staph. & 1 & - & - & + & - & - & + & + & - & + & - \\
\hline \multirow[t]{3}{*}{ aureus } & 2 & + & + & + & + & + & + & + & + & + & + \\
\hline & 3 & + & + & + & + & + & + & + & + & + & + \\
\hline & 4 & + & + & - & + & - & + & + & + & + & - \\
\hline \multirow[t]{4}{*}{ Proteus sp. } & 1 & + & + & - & - & - & - & - & + & - & - \\
\hline & 2 & + & + & + & + & + & + & + & + & + & + \\
\hline & 3 & + & + & + & + & + & + & + & + & + & + \\
\hline & 4 & + & + & - & - & + & + & + & + & - & + \\
\hline \multirow[t]{4}{*}{ S. typhi } & 1 & - & - & - & - & + & - & - & - & - & + \\
\hline & 2 & + & + & - & + & + & + & + & - & + & + \\
\hline & 3 & + & - & + & + & + & - & - & - & + & + \\
\hline & 4 & + & - & + & + & - & - & + & - & - & + \\
\hline C. & 1 & + & + & + & + & + & + & + & + & + & + \\
\hline \multirow[t]{3}{*}{ perfringens } & 2 & + & + & + & + & + & + & + & + & + & + \\
\hline & 3 & + & + & + & + & + & + & + & + & + & + \\
\hline & 4 & + & + & + & + & + & + & + & + & + & + \\
\hline \multirow[t]{4}{*}{ S. faecalis } & 1 & + & + & + & + & + & + & + & + & + & + \\
\hline & 2 & + & + & + & + & + & + & + & + & + & + \\
\hline & 3 & + & + & + & + & + & + & + & + & + & + \\
\hline & 4 & + & + & + & + & + & + & + & + & + & + \\
\hline \multirow{4}{*}{$\begin{array}{l}\text { Pseudomonas } \\
\text { sp. }\end{array}$} & 1 & + & - & + & + & + & 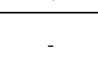 & + & + & + & + \\
\hline & 2 & + & + & + & + & + & + & + & + & + & + \\
\hline & 3 & + & + & + & + & + & + & + & + & + & + \\
\hline & 4 & + & + & + & + & + & + & + & + & + & + \\
\hline \multirow{4}{*}{$\begin{array}{l}\text { Microoccus } \\
\text { sp. }\end{array}$} & 1 & & & + & & + & 1 & - & & & - \\
\hline & 2 & + & + & $\stackrel{+}{+}$ & + & - & + & + & + & - & + \\
\hline & 3 & + & + & - & - & + & + & + & + & + & - \\
\hline & 4 & + & + & - & + & + & + & - & - & + & + \\
\hline \multirow{4}{*}{$\begin{array}{l}\text { Acetobacter } \\
\text { sp. }\end{array}$} & 1 & - & - & - & + & & - & + & & & - \\
\hline & 2 & + & - & + & + & + & + & - & + & + & - \\
\hline & 3 & + & + & - & + & - & - & + & + & - & + \\
\hline & 4 & - & - & + & + & - & + & - & - & + & + \\
\hline \multirow[t]{4}{*}{ A. niger } & 1 & + & + & + & + & + & + & + & + & + & + \\
\hline & 2 & + & + & + & + & + & + & + & + & + & + \\
\hline & 3 & + & + & + & + & + & + & + & + & + & + \\
\hline & 4 & + & - & + & + & + & - & + & + & + & + \\
\hline \multirow[t]{4}{*}{ A. fla vus } & 1 & $t$ & $t$ & + & + & $t$ & + & + & + & $t$ & + \\
\hline & 2 & + & + & + & + & + & + & + & + & + & + \\
\hline & 3 & + & + & + & + & + & + & + & + & + & + \\
\hline & 4 & + & + & + & + & + & + & + & + & + & + \\
\hline Penicillum & 1 & + & + & + & + & + & + & + & + & + & + \\
\hline \multirow[t]{3}{*}{ sp. } & 2 & + & + & + & + & + & + & + & + & + & + \\
\hline & 3 & + & + & + & + & + & + & + & + & + & + \\
\hline & 4 & + & + & + & + & + & + & + & + & + & + \\
\hline \multirow[t]{4}{*}{ G. candidum } & 1 & + & - & - & + & + & + & + & + & + & + \\
\hline & 2 & - & + & + & + & + & - & + & + & + & + \\
\hline & 3 & + & + & + & + & + & + & + & + & + & + \\
\hline & 4 & + & + & - & + & + & + & - & - & + & + \\
\hline
\end{tabular}


Table 3: Summary of the physicochemical properties of sample stations, Sept, 2002 - Jan., 2003.

\begin{tabular}{|c|c|c|c|c|}
\hline Properties & Station 1 & Station 2 & Station 3 & Station 4 \\
\hline Physical n(10) & mean \pm S.E. & mean \pm S.E. & mean \pm S.E. & mean \pm S.E. \\
\hline Atmos. Temp. & $27.7 \pm 0.76$ & $28.5 \pm 0.84$ & $27.9 \pm 0.83$ & $27.95 \pm 0.684$ \\
\hline Water temp. $\left({ }^{\circ} \mathrm{C}\right)$ & $26.5 \pm 0.69$ & $27 \pm 0.75$ & $26.45 \pm 0.807$ & $26.75 \pm 0.573$ \\
\hline Water velocity $\left({ }^{\circ} \mathrm{C}\right)$ & $0.721 \pm 0.04$ & $0.59 \pm 0.023$ & $0.57 \pm 0.025$ & $0.498 \pm 0.020$ \\
\hline \multicolumn{5}{|l|}{ Total Suspended } \\
\hline & $24.03 \pm 0.84$ & $67.35 \pm 77.93$ & $59.75 \pm 7.3$ & $52.22 \pm 7.312$ \\
\hline \multicolumn{5}{|l|}{ Total Dissolved } \\
\hline Solids (mgl $\left.\mathbf{l}^{-1}\right)$ & $42.98 \pm 3.45$ & $105.06 \pm 6.51$ & $97.31 \pm 6.22$ & $88.37 \pm 6.213$ \\
\hline Total Solids & $67.01 \pm 4.24$ & $172.35 \pm 14.31$ & $157.01 \pm 13.27$ & $140.35 \pm 13.31$ \\
\hline pH & $6.73 \pm 0.029$ & $6.15 \pm 0.049$ & $6.14 \pm 0.048$ & $6.52 \pm 0.066$ \\
\hline Conductivity & $51 \pm 2.67$ & $92.8 \pm 6.17$ & $84.7 \pm 4.876$ & $70.8 \pm 5.280$ \\
\hline Hardness & $12.08 \pm 0.12$ & $10.81 \pm 0.029$ & $10.52 \pm 0.105$ & $10.24 \pm 0.096$ \\
\hline Dissolved Oxygen & $9.1 \pm 0.35$ & $7.68 \pm 0.0228$ & $7.08 \pm 0.267$ & $8.1 \pm 0.301$ \\
\hline Biological Oxygen & & & & \\
\hline Demand & $5.07 \pm 0.19$ & $6.83 \pm 0.122$ & $6.28 \pm 0.154$ & $6.37 \pm 0.109$ \\
\hline Nitrate & $0.156 \pm 0.019$ & $0.157 \pm 0.011$ & $0.132 \pm 0.008$ & $0.085 \pm 0.005$ \\
\hline Phosphate & $00.28 \pm 0.023$ & $0.218 \pm 0.016$ & $0.18 \pm 0.015$ & $0.138 \pm 0.012$ \\
\hline Sulphate & $0.39 \pm 0.032$ & $0.38 \pm 0.010$ & $0.36 \pm 0.019$ & $0.326 \pm 0.016$ \\
\hline Iron & $0.25 \pm 0.013$ & $0.545 \pm 0.016$ & $0.537 \pm 0.018$ & $0.352 \pm 0.010$ \\
\hline Lead & $0.435 \pm 0.028$ & $0.29 \pm 0.007$ & $0.28 \pm 0.013$ & $0.226 \pm 0.01$ \\
\hline Chromium & $0.029 \pm 0.004$ & $0.03 \pm 0.05$ & $0.03 \pm 0.005$ & $0.015 \pm 0.002$ \\
\hline Copper & $0.43 \pm 0.013$ & $0.49 \pm 0.017$ & $0.50 \pm 0.019$ & $0.42 \pm 0.009$ \\
\hline Manganese & $0.39 \pm 0.003$ & $0.049 \pm 0.0043$ & $0.05 \pm 0.004$ & $0.023 \pm 0.003$ \\
\hline Zinc & $0.465 \pm 0.021$ & $0.577 \pm 0.018$ & $0.56 \pm 0.016$ & $0.495 \pm 0.016$ \\
\hline Cadmium & $0.071 \pm 0.005$ & $0.087 \pm 0.008$ & $0.09 \pm 0.007$ & $0.063 \pm 0.008$ \\
\hline
\end{tabular}




\section{Discussion}

This research has showed the various effects of human activities and oil pollution on the microbiological and physicochemical qualities of Udu River. There was increase in the most of the parameters studied with little fluctuations. In the study, human activities and oil pollution effect were observed to play significant role in the influence on the qualities of the parameters investigated. Benka-Coker and Ohimian (12) noted that increased human activities could bring about increase in organic matter thereby leading to high microbial load. The introduction of waste water, increased amount of organic matter and essential nutrients brings about changes in the microflora (13). The heterotrophic bacteria and aerobic pathogenic bacteria make up the total bacterial load of river systems. Sayler et al. (14) reported that high microbial population in an aquatic system is a reflection of the input of microorganisms from extraneous sources and availability of growth supporting organic matter. Anson and Ware (6) noted that high counts of bacterial load reflected the level of water pollution as it gave indication of the amount of organic matter present. These findings correlate with the results of the effect of human activities and oil pollution on the microbiological and physicochemical qualities of Udu River, Warri, Nigeria.

The presence of hydrocarbon utilizing microorganisms in Udu Rive could be attributed to the regular transportation of oil and its products across the river as well as the presence of hydrocarbons of biogenic origin. The counts for this group of microorganisms in stations 2 and 3 were again higher than those of stations 1 and 4, which may be due to the increased human activities around these stations. Atlas and Bartha (15) noted that outside the natural input of carbon into aquatic habitats, organic compounds enter the ecosystem through human activities (16).

The presence of total coliforms, E. coli, feacal Streptococci and Clostridium perfringens in the water samples during sampling period indicated faecal pollution of the water due to human activities. The high densities of faecal indicator organisms observed at all the station in station 2 is indicative of faecal pollution. Akpata and Ekundayo (17) reported high faecal load with concentration of $\mathrm{E}$. coli in the Lagos Lagoon.
The increased microbial load during the dry season may be attributed to surface water runoff, urban runoff, reduced water volume and increased activities.

The physicochemical parameters investigated showed some variation along the sampling stations (Table 3). The temperature range obtained throughout the sampling period was within the WHO range of $10^{\circ} \mathrm{C}$ to $50^{\circ} \mathrm{C}$ for surface water (7). The conductivity range of the various stations varied considerably between inhabited and uninhabited stations. Station 2 showed the highest value and therefore decreased along the sampling stations, probably due to effect of dilution and removal of soluble salts by biological utilization. Similar results have been reported by others workers $(18,19)$.

The concentrations of nitrate, sulphate and phosphate in all the sampling stations were quite low, expect in station 2, which was reported to be due to increased human activities and oil pollution effect. Concentration of dissolved oxygen was highest in station 1 with stations 2 and 3 having lower counts than station 4 , this could be due to increased waste disposal at stations 2 and 3 and other form of human activities that may enhance their growth and proliferation, leading to consumption of available oxygen.

Conclusively, it was observed that human activities has impacted negative influence on the quality of water around stations 2 and 3 with station 4 suffering from impact of the upstream stations. The high microbial load as well as high densities of hydrocarbon utilizing microbes suggested oil pollution of the water and high $\mathrm{BOD}_{5}$ of the inhabited stations as well as high anions concentrations along the river course and other observations can be used to classify the Udu river as polluted, unfit for direct human consumable needs in accordance with the international standards for classifying surface waters.

\section{References}

1. Prescott LM, Harley JP, Klein DA. Microbiology. $4^{\text {th }}$ edn. New York: McGraw Hill; 2000.

2. Udo KR. Geographical Region of Nigeria. London: Heinemann Educational; 1975. 
3. Egborge ABM. Hydrobiology of Warri River. Unpublished; 1982.

4. Thurman R, Foulkner B, Veal D, Gramer G, Meiklejohn M. Water quality in rural Australia: J Appl Microbiol 1998; 84:627 - 632.

5. Miller JE. Water pollutants and public health: Microbiology. $3^{\text {rd }}$ edn. New York: John Wiley and Sons; 2001.

6. Anson AE, Ware GL. Survey of distribution of bacterial population in Bristol Channel. J Appl Bacteriol 1974; 37:657 - 661.

7. World Health Organization International Standard for Drinking Water. $3^{\text {rd }}$ edn. WHO Geneva: Switzerland; 1971.

8. American Public Health Association / American Water Pollution Control Federation. Standard methods for examination of water and waste. 17th edn. Washington, DC: APHA; 1989.

9. Gerhardt P, Murray EGR, Wood AW, Krieg RN. Methods for General and Molecular Bacteriology. Washington: ASM Press DC; 1994.

10. Buchanan RE, Gibbons NE. Bergey's Manual of Determinative Bacteriology. $8^{\text {th }}$ edn. Baltimore: Williams and Wilken; 1974.

11. Barnett HL, Hunter BB.Illustrated genera imperfect fungi. $3^{\text {rd }}$ edn. New York: Burgress; 1972.
12. Benka-Coker MO, Ohimian EI. Investigation of spatial variation in bacterial distribution in surface waters of Ikpoba River. Nig J Microbiol 1995; 10:27 - 32 .

13. Rheinheimer G. Aquatic Microbiology. $4^{\text {th }}$ edn. New York: John Wiley and Sons; 1991.

14. Sayler GS, Nelson JO, Justice A, Colwell RR. Distribution and significance of faecal indicator organisms in the upper Chasepark Bay Appl Indust Microbiol 1975; 30(4): 625 - 638.

15. Atlas RM, Bartha R. Microbial Ecology: Fundamentals and Applications. $3^{\text {rd }}$ edn. California: Benjamin; 1993.

16. Benka-Coker MO, Ojior OO. Effect of slaughterhouse wastes on the quality of Ikpoba River, Benin City. Bioresource Technology 1995; 52: 5 - 12 .

17. Akpata VI, Ekundayo JA. Faecal pollution of Lagos Lagoon. Nig J Sci 1978; 12: 39 - 53.

18. Egborge ABM, Fagade SO. Notes on the hydrobiology of the Wikki Warm Spring, Yankari Game Reserve, Nigeria. Pollut Arch Hydrobiol 1999; 26(3):313 - 322.

19. Nkwodimah CN. Bacteriological and physicochemical quality of Ojirami Dam. Nigeria: MSc Thesis University of Benin; 1985.

Recebido em / Received: January 4, 2005. Aceito em / Accepted: February 6, 2006. 